\title{
Scale and Elasticity Properties of Turkish Agricultural Production Function: Political Economy Approach
}

Deniz GÜVERCIN (https://orcid.org/0000-0001-6158-3877), Department of International Trade and Finance, Istanbul Arel University, Turkey; e-mail: denizguvercin@arel.edu.tr

\section{Türk Tarım Fonksiyonunun Ölçek ve Elastikiyet Özellikleri: Politik Ekonomi Yaklaşımı}

\begin{abstract}
In this study, factor elasticities, value of marginal products, and the return to scale are estimated for Turkish agricultural production function by employing Turkish Regional Statistics for the period of 1994-2003. Results imply that there is an increasing return to scale, land has highest factor elasticity, and tractor has highest value of marginal product. We claim that the presence of increasing returns to scale is related to fragmented and scattered land, and small-scale farming in Turkey. Moreover, we claim that the high output and employment share of agriculture are related to populist corporatist politics. In this study, we also emphasize that reasons behind rural areas to be overpopulated are also reasons behind fragmented and small-scale farming, and sluggish movement of agricultural labor to other sectors.
\end{abstract}

Keywords

Agricultural Production Function, Return to Scale, Marginal Product, Factor Elasticity, Small Scale Farming.

JEL Classification Codes : Q12, Q15, C51.

\section{$\ddot{O} z$}

Bu çalışmada 1994-2003 dönemi için bölgesel veriler kullanarak tarımsal çıktının girdilere göre elastikiyetleri, girdilerin marjinal ürün değerleri ve üretimin ölçeğe göre getiri durumu tahmin edilmiştir. Sonuçlar; Türkiye tarımında ölçeğe göre sabit getiri durumunun olmadığını, artan getiri durumunun var olduğunu, tarımsal çıktının arazi büyüklüğüne göre esnekliğinin en yüksek esneklik değeri olduğunu, traktörün en yüksek marjinal ürün değerine sahip olduğunu göstermektedir. Üretimde ölçeğe göre artan getirinin, Türkiye'de tarımın parçalı, küçük ölçekte yapılması ile ilişkili olduğunu öne sürmekteyiz. Çalışmada, bulgular sosyo-politik yönden ele alınmakta ve Türkiye'de tarımın ekonomik ve sosyolojik olarak önemini kaybetmemesinin popülizmin bir sonucu olduğu iddia edilmektedir. Çalışmada, kırsal kesimlerin nüfusun biriktiği bir alan olarak var olmaya devam etmesini sağlayan nedenlerin aynı zamanda parçalı, küçük ölçekte üretimi özendirdiği ve emeğin sektörler arası hareketini sınırlandırdığı da iddia edilmektedir.

Anahtar Sözcükler $\quad$ : Tarımsal Üretim Fonksiyonu, Ölçeğe Göre Getiri, Marjinal Ürün, Faktör Esnekliği, Küçük Ölçekli Tarım. 


\section{Introduction}

In 1960, the share of employment in agriculture was $76 \%$ in Turkey, $57 \%$ in Greece, and $42 \%$ in Spain which changed through years. By 2008, the share of employment had decreased to $24 \%$ in Turkey, $11 \%$ in Greece, $4 \%$ in Spain (Imrohoroglu et al, 2014). These numbers indicate that Turkey has been experiencing sluggish transition away from agriculture dependent economy compared to European Union countries. The paper analyses the structural conditions enabling this sluggish structural transformation of Turkish agriculture.

In Turkey, agricultural sector until late 1980s had greatest shares from government budget not just because it employs most of the labor force in the country, but also it provides industrial inputs and foreign exchange for the country. The share of agriculture in total exports remained above 80 percent through the 1960s, and above 60 percent through the 1970s, and then decreased to 10 percent by 2008 (Pamuk, 2008).

One of the main characteristics of the Turkish agriculture is that it is based on smallscale family farms. Because it is sub-optimal to invest in modern technologies and production processes for small-scale farms, labor productivities are very low. Low education levels in rural areas, low (unskilled) labor absorbing capacities of cities, populist corporatist politics aiming to gain rural votes, adapted inheritance laws are main reasons of land fragmentation and small-scale farming in Turkey.

Due to labor saving technologies, the role of agriculture in the economy changed dramatically from labor absorbing sector to labor transferring sector for the entire industry. After the collapse of Ottoman Empire, Turkey put new strategies to promote industrialization. We argue that the transition from agriculture to industry are product of the socio-economic and political conditions of Turkey.

In other words, we argue that politic and economic initial conditions along with capital accumulation strategies in the general economy affect the scale of production and technology adapted, resulting in particular transformation path of Turkish agricultural sector. The study is an attempt to put forward the structure of Turkish agricultural production, relate it with factor elasticities of the production and returns to scale with adapted politic and economic modernization strategies.

The paper estimates the input elasticities for the agricultural production function of Turkey by using Cobb-Douglas production function. Value of marginal products for inputs of production, and returns to scale for production function are also estimated using Ordinary Least Square (OLS) estimation method. The period for the empirical estimation is 19942003, and the study covers 12 regions of Turkey. There are three main sections in the paper. The first section explores the historical conditions in Turkish agriculture by emphasizing the role of agriculture in development strategies that are adapted. The second section illustrates the Turkish agriculture in terms of its share in employment and total value added compared 
to European countries. In the last section empirical model is estimated and policy implications are discussed.

\section{Structure of Turkish Agricultural Production and Employment in Retrospective}

Main characteristic of the Turkish agriculture is that it depends heavily on small-scale farming and independent peasantry. These small-scale farms outnumber the large scale farms, and farmers in small scale farms do not emigrate or invest in land and technology to make large scale farming (Basarir et al., 2006). Along with small scale farming, fragmented and scattered farms, low productivity, and low marginal product of labor due to over employment in agricultural sector are other main characteristics of Turkish agriculture (Olhan, 2006). Under the guidance of international organizations, Turkey dismantled public supports such as price support schemes, credit subsidies for agricultural sector.

Turkey had adapted agricultural polices based on government support in capitalization, commercialization and commoditization of agriculture from 1930 to late 1970s. Governments of this period provided input, credits and improved the economic conditions of obtaining technological equipment, adapting crop varieties (Aydin, 2010). Debt related problems, industrialization policies and new international division of labor serving the needs of capital accumulation, and pressures from international agencies on liberalization of agriculture led to decline in public support for agricultural development. Liberalization of agriculture in Turkey leads to shift to production of high value foods, and crops used as industrial inputs from traditional crops such as tobacco, cereals, and sugar beet (Aydın, 2010).

Agriculture sector has been losing its significance in the general economy since 1990s whereas share of agricultural subsidies in the government budget has been declining. Keyder and Yenal (2011) argue that Turkey followed state-led development strategy and adapted market oriented globalized economy framework for development after 1990s. Most of the major reforms to suppress agricultural support by government were undertaken following 2001 economic crisis (Dudu et al., 2015).

Government subsidies in terms of mostly price dominant support policy tools that had been used in agriculture sector of Turkey were declined after 1999. Following the year 2000 , the amount of support and subsidies were cut which led to inequality in income distribution, populism, and inefficient usage of public resources (Ates et al., 2017). Withdrawal of government institutions as producer and organizer from agricultural sector leads to increased presence of foreign capital through privatization. Turkey and the World Bank signed the Agricultural Reform Implementation Program (ARIP) in 2001 which had a significant impact on the degree of public support for agricultural sector (Dudu et al., 2015). ARIP aims to decrease price and credit subsidies and replace them with Direct Income Support (DIS) (Olhan, 2006). Olhan (2006) reports that cost-benefit analysis of DIS suggests that it did not affect welfare of the producers. On the contrary, it could not substitute the 
income loss that was experienced after the suppression of input and credit subsidy by producers.

Along with ARIP, some policies were adapted to comply with EU Common Agriculture Policy. Following these policies, migration to cities, unemployment, and poverty and income inequality increased, price of inputs increased and price of output decreased. Particularly, farmers of small-scale farms who should have been supported to use optimal size of the farm are migrated to cities that, in turn, has led to the shrinkage of cultivated land (Ates et al., 2017). Small-scale farming has been losing its significance, even it still is very dominant form of farming, and de-peasantization has been taking place. Another very significant result of adapting reduced government intervention, and more market orientation in agricultural sector is that smallholders become exposed to price fluctuations and sudden income shocks which put them in indebted position and exposed to interest rate fluctuations as well.

\section{Table: 1}

Statistics on size of Farms, Cultivated Area

\begin{tabular}{|c|c|c|c|c|c|c|}
\hline \multirow[b]{2}{*}{ Farm Size } & \multirow[b]{2}{*}{ Number of Farms } & \multirow[b]{2}{*}{ Share of Farms $(\%)$} & \multirow[b]{2}{*}{$\begin{array}{c}\text { Irrigated Share of } \\
\text { Area }(\%)\end{array}$} & \multicolumn{3}{|c|}{ Cultivated AREA } \\
\hline & & & & Size & Share $(\%)$ & $\begin{array}{c}\text { Share of } \\
\text { Irrigated Area }(\%)\end{array}$ \\
\hline Small (5<Ha) & 1.958 .281 & 64,8 & 43,9 & 39.331 .138 & 21,3 & 21,5 \\
\hline Medium (5-20 Ha) & 887.328 & 29,4 & 40,9 & 82.004 .847 & 44,5 & 18,0 \\
\hline Large $(20 \mathrm{Ha}+)$ & 175.598 & 5,8 & 41,8 & 62.993 .516 & 34,2 & 18,8 \\
\hline Total & 3.021 .207 & 100,0 & 42,9 & 184.329 .501 & 100,0 & 19,0 \\
\hline
\end{tabular}

Source: Ucak, 2006.

Table 1 indicates that Turkish agriculture is based on small-scale farming where the small sized farms are the majority; $65 \%$ of total number of farms. Number of large farms is small; 5.8\% of total farms, however their share in total cultivated area is $34 \%$. Application of labor saving technologies is limited for small scale farming, which causes high value added and employment share of agriculture. It can be argued that Turkish Agricultural sector would have been more efficient if the production scale was larger, which would have made early adaption of cutting-edge agricultural technologies for large scale production.

The World Bank was promoting state led agricultural development, and small scale farming during the period of 1960-1970. Populist politics was based on the vote maximization through providing credit and price subsidies for peasantries. Therefore, both internal and external institutions were weathering for supportive agricultural policies aiming for peasants and small-scale farms before late 1980s.

However, short-sighted political arrangements resulted in the misallocation of society's resources to the economically inefficient areas. Particularly, political arrangements through providing subsidies halted profit seeking agricultural production activities, which led to inefficient usage of resources. Farmers did not adapt cutting edge technologies in production leading to sub-optimal size of farming. Therefore, agricultural labor stocks still have not depleted, rural areas have remained over populated for long time, and small-scale farming has not lost its popularity. 
Particularly during pre-election periods, economic policies aiming to increase the vote share of the incumbent party misallocated the national resources leading to economic underdevelopment and fiscal burden in Turkey. Structural transformation of the Turkish economy and state of the agricultural sector in Turkey were affected mainly by shortsighted political motives and arrangements. Describing the extent of populism in rural areas, Guven (2009: 169) argues that "Rural interests were functionally organized into compulsory, noncompetitive, state-funded and state-supervised regional/national associations that aided, in varying capacities, government agencies in executing support policies".

\section{Perspective on Turkish versus European Countries' Agricultural Development}

Table 2 indicates that Turkey is not very behind from developed countries in terms of number of tractors. On the other hand, the share of agricultural employment in total employment is highest in Turkey. Additionally, the table displays that female population is employed mostly in the agricultural sector and agricultural sector contributes significantly to the Gross Domestic Product compared to other countries in the table. These indicators suggest the facts that the agricultural sector was the primary source of employment in Turkey, and it was still agrarian society over the period of 1994-2003.

Table: 2

\begin{tabular}{|c|c|c|c|c|c|c|}
\hline Variables & Turkey & USA & Italy & Germany & Brazil & Crotia \\
\hline Tractors & 855929 & 4447270 & 1603437 & 1125085 & 795600 & 305122 \\
\hline Land ( $\%$ of land area) & 52.2 & 45.4 & 52.5 & 49.3 & 31.2 & 31 \\
\hline Employment (\% of total employment) & 39.5 & 2.6 & 5.6 & 2.8 & 22.5 & 16.1 \\
\hline Female Employment ( $\%$ of female employment) & 65,8 & 1,41 & 4,95 & 2,36 & 17,933 & 16.55 \\
\hline Fertilizer (per hectare) & 78,54531 & 116,039 & 174,4122 & 219,8861 & 136,573 & 274.895 \\
\hline GDP per capita & 5812,962 & 38652,76 & 29847,26 & 32597,67 & 4338,62 & 8019,73 \\
\hline
\end{tabular}

Source: World Bank Development Indicators, 2015.

We already discussed the main reasons behind sluggish structural transformation. There are also some related reasons causing over employment in agricultural sector. Because rural areas lack educational infrastructure, average education level in rural areas is lower than urban areas in Turkey. Therefore, migration from villages to cities started in 1960s, which led to stock of unemployed unskilled (farm) workers in cities. On the other hand, the lack of skills in rural labor and low wage for unskilled labor in cities led many farmers to employ their children on the family farm. It can be argued that under investment in education in rural areas contributed to low labor productivity, stock of unskilled labor and high employment level in rural areas, which were employed at small family farms. On the other hand, government provision of supports shielded smallholders even they were using labor with low marginal product.

Another important point should be emphasized regarding Turkish agriculture is its export potential, which is another explanation for late transformation of Turkish agriculture. The share of agriculture in total exports remained above 80 percent through the 1960 s, and above 60 percent through the 1970s. The agricultural sector thus provided the much-needed foreign exchange in the early stages of Turkey's import substituting industrialization. After 
the populist corporatist polices ended in 1980, exports of manufactured goods began to increase rapidly. By year 2000, the share of exports in Turkish GDP had risen to 14 percent and the share of agriculture in total exports had declined to less than 10 percent (Pamuk, 2008).

Additionally, construction of the new automobile industry, transportation networks, highways were very late in Turkey compared to other European countries which decreased the pace of release of rural labor. The Marshall Aid was used for the construction of Turkish railroads and transportation networks and to buy tractors, which increased the productivity of labor. The number of tractors was over 1 Million in 2010, and is used approximately at all farms in Turkey except some very small sized farms or lands (in some very small scaled farms, which counts very small portion, still animal power is used). With the help of the Marshall Plan and the agricultural reforms implemented in later years, new seeds and fertilizers were used, which contributed to the productivity of land.

Tables below illustrate the labor and land productivities of some European countries along with Turkey. Tables indicate that Turkey is the least productive for both labor and land compared to other European countries. The numbers for land and labor productivities reflect that Turkey has different transformation phase than other countries in the Europe.

Along with political reasons, inheritance law resulted in small-scale farms through share of land (fragmentation) among family members. Due to fragmented land, investing in technology and using optimal scale of technology are not feasible, which also cause low productivity levels. Tan et al (2006) argue that small-scale farming deters modern agricultural development and large-scale mechanization. From 1960s onward, there have been efforts to consolidate agricultural land in Turkey. Akkaya et al (2007) report that 724 land consolidation (LD) projects performed over the period of 1961-2007.

Table: 3

\begin{tabular}{|c|c|c|c|c|c|c|c|}
\hline Year & France & U.K. & Italy & Spain & Greece & Bulgaria & Turkey \\
\hline 1890 & 100 & 128 & 146 & 58 & & & 41 \\
\hline 1910 & 98 & 133 & 158 & 54 & & & 46 \\
\hline 1930 & 105 & 161 & 189 & 64 & & & 44 \\
\hline 1950 & 143 & 159 & 192 & 66 & & & 47 \\
\hline 1960 & 172 & 210 & 282 & 98 & 100 & 74 & 50 \\
\hline 1980 & 274 & 348 & 414 & 192 & 180 & 132 & 77 \\
\hline 2000 & 310 & 407 & 464 & 275 & 200 & 88 & 124 \\
\hline
\end{tabular}

Table: 4

Labor Productivity per worker (U.K. 1890= 100)

\begin{tabular}{|c|c|c|c|c|c|c|c|}
\hline Year & France & U.K. & Italy & Spain & Greece & Bulgaria & Turkey \\
\hline 1890 & 100 & 72 & 45 & 38 & & & \\
\hline 1910 & 102 & 84 & 46 & 33 & & & \\
\hline 1930 & 116 & 102 & 50 & 45 & & & \\
\hline 1950 & 184 & 131 & 52 & 35 & & & \\
\hline 1960 & 259 & 197 & 88 & 60 & 90 & 30 & 38 \\
\hline 1980 & 686 & 617 & 288 & 281 & 200 & 100 & 62 \\
\hline 2000 & 920 & 1600 & 800 & 680 & 300 & 200 & 110 \\
\hline
\end{tabular}

Table 5 and 6 display the size of Research and Development (R\&D) expenditures in Turkey compared to EU countries. Turkey lags behind of developed nations of EU in terms 
of R\&D. R\&D expenditures provide infrastructure in terms of researchers, facilities, patents which would increase productivity and efficiency in agriculture.

Table: 5

Gross Domestic Expenditure on R\&D in Turkey \& in European Union ${ }^{1}$

\begin{tabular}{cccccc}
\hline Year & Turkey & Spain & Italy & France & Greece \\
\hline 2000 & 2,996 & 9,193 & 16,411 & 36,946 & 1449 \\
2003 & 3,184 & 11,657 & 17,766 & 38,794 & 1670 \\
2006 & 4,845 & 14,832 & 19,095 & 40,191 & \\
2010 & 7,664 & 17,240 & 20,606 & 43,214 & \\
\hline
\end{tabular}

Source: OECD Statistics, 2010.

Table: 6

Share of Agricultural Knowledge and Innovation System in Total GSSE ${ }^{2}$

\begin{tabular}{lccc}
\hline & Turkey & United States & European Union (28 Countries) \\
\hline 2000 & 0.56 & 31.5 & 43.7 \\
2005 & 1.51 & 26.1 & 41.5 \\
2010 & 2.4 & 23.8 & 45.3 \\
2015 & 6.5 & 26.1 & 52.1 \\
\hline
\end{tabular}

Source: OECD Agricultural Database, 2017.

\section{Applied Agricultural Production Analysis on Turkey}

There are some applied agricultural production analysis on Turkey. Most of the studies using agricultural production function estimate the Total Factor Productivity (TFP) either at province level or at regional level, and they estimate the input elasticities for agricultural good.

Basarir et al. (2006) analyzed productivity growth and technical changes in Turkish agriculture by using the data for the period of 1961-2001, and by adapting C-D production function. They report that agricultural output grew by $1.3 \%$ to $3.4 \%$ annually and labor, fertilizer, irrigation and tractors explain most of the increase in the agricultural output. They also report that growth rate of technical change varies in the range of $-0.15 \%-5.53 \%$.

Armagan and Ozden (2007) estimate the input efficiencies, and returns to scale for crop producing farms by using the data for province of Aydin in Turkey and by adapting C$\mathrm{D}$ production function for empirical analyzes. They report that increase in farm size leads to TFP increase. They also report that gross production value increases for medium size farm, if land size is increased.

By using the data for crop production of NUTS1 regions over the period of 19942003, Armagan et al (2008) analyzed the TFP level in the regions through Data Envelopment Analysis (DEA). They report that the levels of technical efficiency and total factor

1 In Million US Dollars-2005 constant prices and PPPS.

2 GSSE is the abreviation for General Service Support Estimate representing transfers granted to produces collectively. 
productivity in these regions decrease due to increase in input prices, and reports that difficulty is experienced at integration of latest technologies into the agricultural production.

Semerci et al. (2012) estimate the factor elasticities and returns to scale by using the data for wheat production in Turkey for the year of 2007 and by adapting C-D production function for empirical analyzes. They report that land quality, fertilizer cost, pesticide cost increases the wheat production, and they also report that there exists increasing returns to scale.

By using household survey data for the years of 2002 and 2004 in Turkey, Dudu et al. (2015) estimated stochastic production frontier and examined the relative importance of factors of production and their interactions with various characteristics of farms. They report that agricultural production in Turkey highly dependent on land whereas labor is over employed in the agricultural sector. They also report that farm size, crop patterns, education level of household chief, and irrigation are found to be effective on efficiency.

Ozsabuncuoglu (1998), used the data for wheat production at Gaziantep, Sanliurfa, Diyarbakir, and Mardin provinces in Southeastern Turkey over the period of 1963-1989. He adapted C-D production function to estimate the input elasticities of wheat production. He reports that wheat production is affected by cultivation area, fertilizer usage, and rainfall. He also reports that there exist increasing returns to scale for wheat production.

\section{Empirical Model}

\subsection{Model Baseline}

In this section of the paper, we estimate technical properties of the Turkish agricultural production using Cobb- Douglas type production function where fertilizer, labor, land and tractor are factors of production.

The Cobb-Douglas function has some desired properties for econometric analysis. It has few parameters, easy to transform to logarithmic form, easy to estimate, and it does not permit inputs to have negative marginal values. Additionally, the returns to scale for agricultural production function (decreasing, constant or increasing returns to scale) can be obtained with this functional form. Moreover, if the logarithmic form is used for estimation, the estimated coefficients are equal to output-input elasticities.

Ordinary Least Square (OLS) method over C-D function is used for estimation. Fertilizer, labor, land and tractor are independent variables explaining the variation in the agricultural output in the empirical model.

Returns to scale represents the increase in the output compared to increase in factors of production. If there is increasing returns to scale, then quantity of production increases proportionally more than factors of production. If there are decreasing returns to scale, then quantity of production increases proportionally less than factors of production. If there are 
constant returns to scale, then quantity of production increases at same proportion with factors of production. The mathematical representation for that statement is as follows;

$\mathrm{Z} . \mathrm{Y}=\mathrm{F}(\mathrm{Z} \cdot \mathrm{K}, \mathrm{Z} \cdot \mathrm{L})$ if the returns to scale is constant

Z.Y > F(Z.K,Z.L) if the returns to scale is decreasing

Z.Y $<F(Z . K, Z . L)$ if the returns to scale is increasing ${ }^{3}$

The returns to scale for two inputs Cobb-Doulas Production function can be obtained through the following:

$\mathrm{F}(\mathrm{tK}, \mathrm{tL})=\mathrm{t}^{\mathrm{k}} \mathrm{F}(\mathrm{K}, \mathrm{L})$

If $\mathrm{k}=1$ then the returns to scale is constant, if $\mathrm{k}>1$ then it is increasing returns to scale, if $\mathrm{k}<1$ it is decreasing returns to scale. For particular $\mathrm{C}-\mathrm{D}$ function:

$\mathrm{F}(\mathrm{K}, \mathrm{L})=\mathrm{K}^{\gamma} \mathrm{L}^{\beta}$

$F(t K, t L)=(\mathrm{tK})^{\gamma}(\mathrm{tL})^{\beta}=\mathrm{t}^{\beta+\gamma}\left(\mathrm{K}^{\gamma} \mathrm{L}^{\beta}\right)=\mathrm{t}^{\mathrm{k}} \mathrm{F}(\mathrm{K}, \mathrm{L})$ where $\mathrm{k}$ is $\beta+\gamma$

If $\beta+\gamma=1$ then the returns to scale is constant, if $\beta+\gamma>1$ then it is increasing returns to scale, if $\beta+\gamma<1$ it is decreasing returns to scale.

\subsection{Data}

The source of data set is Turkish Statistics Institute. The time period for the empirical estimation is 1994-2003, and the study covers 12 regions of Turkey. The dependent variable is the value of agricultural production (which is deflated by using base year (1994=100), and is measured in 1000 TL units). Independent variables are; the amount of land cultivated (hectares), the amount of fertilizers including nitrogen, potash and phosphorous (ton), population economically active in the agricultural sector (persons), and the number of tractors for 12 regions for 1994-2003 years.

Table: 7

\section{Descriptive Statistics}

\begin{tabular}{|c|c|c|c|c|c|}
\hline Variable & Number of Observations & Mean & Standard Deviation & Minimum & Maximum \\
\hline Production & 120 & 364869.5 & 262473 & 13466 & 1024120 \\
\hline Fertilizer & 120 & 719015.2 & 503998.9 & 13583 & 1863547 \\
\hline Tractor & 120 & 74041.7 & 51250.99 & 4688 & 210346 \\
\hline Labor & 120 & 693591.7 & 308866 & 264998 & 1407566 \\
\hline Land & 120 & 2215558 & 1253202 & 80647 & 4260901 \\
\hline
\end{tabular}

3 Where the inputs ( $K$ is capital and $L$ is labor) increase by factor of $Z$. 


\subsection{Model}

The following equation is the Cobb-Douglas (C-D) production function used for estimation. $\mathrm{Y}$ is value of agricultural output, $\mathrm{F}$ is amount of fertilizer used, $\mathrm{T}$ is the number of tractors, $\mathrm{N}$ is population active in agriculture, and $\mathrm{L}$ is land cultivated.

$$
\mathrm{Y}=\mathrm{AF}^{\alpha} \mathrm{T}^{\gamma} \mathrm{N}^{\delta} \mathrm{L}^{\theta}
$$

The following equation is the natural logarithm form of C-D function with random disturbance term, which has desired properties of zero mean, constant variance and normally distributed.

$$
\ln \left(\mathrm{Y}_{\mathrm{t}}\right)=\ln (\mathrm{A})+\alpha \ln \left(\text { Fertilizer }_{\mathrm{t}}\right)+\gamma \ln \left(\text { Tractor }_{\mathrm{t}}\right)+\delta \ln \left(\text { Labor }_{\mathrm{t}}\right)+\theta \ln \left(\text { Land }_{\mathrm{t}}\right)+\varepsilon_{\mathrm{t}}
$$

The error term, $\varepsilon_{t}$, includes all variables that are not accounted by other independent variables, i.e. weather, technology shocks. OLS assumes that all these shocks are random, and do not have explanatory power. The estimated parameters are approximate values for real input elasticity of output, which also help to calculate the degree of homogeneity and returns to scale.

Table: 8

Econometric Results

\begin{tabular}{cccc}
\hline Variables & Coefficient & t Values & $\mathbf{R}^{2}$ \\
\hline Constant & $-6,065$ & -4.08 & 0.8392 \\
$\ln$ (Fertilizer) & 0,272 & 4.54 & \\
$\ln ($ Tractor) & 0,112 & 1.69 & \\
$\ln$ (Labor) & 0,378 & 3.87 & \\
Ln(Land) & 0,606 & 8.47 & \\
\hline
\end{tabular}

The coefficients are input elasticities that can be transformed into the relevant marginal products. Following is the transformation of output elasticity with respect to fertilizer into the marginal product of the fertilizer.

$$
\begin{aligned}
& \alpha=\frac{d(\text { Value of Agricultural Product }) / \text { Value of Agricultural Product })}{d(\text { Quantity of Fertilizer }) / \text { Quantity of Fertilizer })} \\
& \alpha=\frac{\text { Quantity of Fertilizer }}{\text { Value of Agricultural Product }} * \frac{d(\text { Value of Agricultural Product })}{d(\text { Quantity of Fertilizer })} \\
& \text { or; } \\
& \alpha * \text { Value of Average Product of Fertilizer = Value of Marginal Product of Fertilizer }
\end{aligned}
$$

We obtain $\alpha$ from C-D estimation, and Average Product (VAP Fertilizer $_{\text {) from }}$ descriptive statistics. The following table illustrates the Marginal Products of inputs using equation 8 above.

Table 9 indicates that land has the lowest value of marginal product; 99 Turkish Lira. It means that if the area harvested increased by 1 hectare, the value of agricultural product shall increase by 99 Turkish Lira in average. Labor has 200 TL value of marginal product. 
Literally, it means that hiring one more person to agricultural production will increase value of output by $200 \mathrm{TL}$ on average. Fertilizer has $138 \mathrm{TL}$ value of marginal product, which is the second from the bottom, and it means that increasing 1 ton of fertilizer will increase value of agricultural product by $138 \mathrm{TL}$. Tractor has highest value of marginal product; 551 TL, which means that adding one more tractor to production process will increase value of agricultural production by $551 \mathrm{TL}$ on average.

Table: 9

Marginal Product Values of Inputs (1000 TL)

\begin{tabular}{cc}
\hline Variables & Values of Marginal Products \\
\hline Fertilizer & .138 \\
Tractor & .551 \\
Labor & .199 \\
Land & .099 \\
\hline
\end{tabular}

\section{Input Elasticities and Returns to Scale}

Elasticity of output with respect to a particular input is the percentage change in output as a response to one percentage change in the particular input. Returns to scale can be found out by summing up all input elasticities for C-D function. For example; if the returns to scale is constant, which means that the production increases in proportion equivalent to proportion of increase in inputs, the input elasticities must be summed up to 1 $(\alpha+\gamma+\delta+\theta=1)$. To check whether the constant returns to scale exists, we statistically test the following hypothesis:

$$
\begin{aligned}
& \mathrm{H}_{0}: \alpha+\gamma+\delta+\theta=1 \\
& \mathrm{H}_{\mathrm{A}}: \alpha+\gamma+\delta+\theta \neq 1
\end{aligned}
$$

Null hypothesis above is based on the fact that the constant returns to scale applies for the Turkish agricultural production function. Alternative hypothesis is based on the fact that constant returns to scale does not apply for the Turkish agricultural production function. Therefore, if the econometric evidence suggests that the null hypothesis should be rejected, then it can be concluded that constant returns to scale does not apply for Turkish agricultural production function.

The sample value of the $\mathrm{F}$ statistic is under 12.40 and $\mathrm{p}$ value is 0.0006 implying that null hypothesis of constant returns to scale is rejected at better than the 1 percent significance level. Hence, constant return to scale in Turkish Agriculture does not exist over the period of the study.

Moreover, econometric estimation suggests that sum of coefficients is more than 1 , hence increasing returns to scale apply for Turkish Agricultural production function. In terms of input elasticities; the land has greatest elasticity of output. If the land increases one percent, the value of agricultural output increases by $0.6 \%$ whereas it is $0.37 \%$ if labor increases one percent, $0.27 \%$ if fertilizer increases one percent, and $0.11 \%$ if tractor increases one percent. Although elasticity of output with respect to land is bigger than tractor, tractor has highest value of marginal product, which is the consequence of the fact 
that tractor has higher value of average product than land, or tractor has lower average cost than land.

One possible explanation for presence of increasing returns to scale in Turkish agricultural production is that there is small scale farming that is not suitable for the application of cutting edge production technology. An expansion of scale of production would enable to apply new production techniques, which is suboptimal in small scale. Changing methods of production would enable different input combinations, which becomes optimal in larger scale resulting in more output per input. From this perspective, we can argue that scale of Turkish agricultural production is small to obtain efficiency benefits out of division of inputs. One policy implication of this result is the promotion of large scale farming that would increase factor productivities and agricultural output. In other words, small-scale farming should be abandoned to complete the structural transformation of agricultural sector.

\section{Discussion and Conclusions}

This study aims to analyze technical characteristics of Turkish Agricultural production function. To this end, Cobb Douglas production function in logarithmic form is used to estimate input elasticities, value of marginal products as well as returns to scale. Estimation results suggest that Turkish agricultural production has increasing returns to scale. Moreover, estimations suggest that land has greatest elasticity of output. If the land increases one percent, the value of agricultural output increases by $0.6 \%$ whereas it is $0.37 \%$ if labor increases one percent, $0.27 \%$ if fertilizer increases one percent, and $0.11 \%$ if tractor increases one percent. Although elasticity of output with respect to land much is bigger than tractor, tractor has the highest value of marginal product, which is the consequence of the fact that tractor has higher value of average product than land, or in other words, tractor has lower average cost than land.

One possible explanation for presence of increasing returns to scale in Turkish agricultural production is that new technologies and methods of production cannot be applied on small-scale farms. Therefore, efficiency benefits arising with adapting new production technology and methods of production that are optimal for large-scale farms cannot be internalized, because small scale farming is common in rural areas of Turkey.

The Turkish Agriculture sector is not pursuing same path of structural transformation with EU countries. The structural transformation is sluggish and weak in Turkey. Employment and value-added share of agriculture are high in Turkey. Turkish agriculture was the sector making major contribution to economy in the beginning of the 20th century. Agriculture sector was the main foreign currency source of Turkey used to support capital accumulation in the non-agricultural sector. Although labor in agriculture had very small value added per capita compared to industry, there was no non-agricultural capacity to absorb a large exit from agriculture to industry. This condition has been manipulated by politicians who provided public resources to agrarian regions to maximize the votes, which resulted in excess labor force in agricultural sector. 
Transformation of Turkish economy from agriculture to industrial economy was sluggish due to populist corporatist politics. Populist approach seeking vote maximization through rural votes caused slow transition to industrialization phase. Politicians in the 1950s and 1960s draw on the rural population to be re-elected.

Because education level in rural areas is low, there was not much gain in terms of net wage income (after taking account adjustment costs) for farm workers in cities. Therefore, rural labor mostly employed in small family farms has led to sluggish transition from agrarian society to capitalist society.

Moreover, Turkey has small size farms; $65 \%$ of total farms, producing just $21 \%$ of total output. Turkish agriculture has recently been moving more rapidly on the transition path. The share of agriculture in GDP has come down from $29 \%$ to the $20.6 \%$ from 2004 to 2015, however, which is around $1 \%$ in developed countries.

The policy implications of the paper are; to increase productivity in Turkish agriculture and to shrink the share of agricultural labor force, the populist corporatist political mechanism should be in check by laws and regulations. More LD projects should be performed to decrease the number of small size farms, R\&D capacity in agriculture needs to be increased and more funds needs to be provided for rural education.

\section{References}

Arianto, A.P. (2007), "Returns to scale in agriculture: A suggested theoretical Framework", Lembaga Penyelidikan Ekonomi dan Masyarakat Fakultas Ekonomi Universitas Indonesia, Staff Paper 4.

Armagan, G. \& A. Ozden \& S. Bekcioglu (2010), "Efficiency and total factor productivity of crop production at NUTS1 level in Turkey: Malmquist index approach”, Quality and Quantity, 44(3), 573-581.

Armagan, G. \& A. Ozden (2007), "Determinations of total factor productivity with Cobb-Douglas production function in agriculture: The case of Aydin-Turkey", J. Applied Sci, 7(4), 499502.

Aslan, S.A. \& K.S. Gundogdu \& E. Yaslioglu \& M. Kirmikil \& I. Arici (2007), "Personal, physical and socioeconomic factors affecting farmers' adoption of land consolidation”, Spanish Journal of Agricultural Research, 5(2), 204-213.

Aydin, Z. (2010), "Neo-Liberal Transformation of Turkish Agriculture”, Journal of Agrarian Change, 10(2), 149-187.

Basarir, A. \& B. Karli \& A. Bilgic (2006), “An evaluation of Turkish Agricultural production performance" Int. J. Agric. Biol, 8(4), 511-515.

Beattie, B.R. \& C.R. Taylor \& J.M. Watts (1985), The Economics of Production, Krieger Publishing Company.

Boratav, K. (2007), Tarımsal Fiyatlar, Istihdam ve Köylülüğün Kaderi, <www.bagimsizsosyalbilimciler.org/Yazilar_Uye/BoratavHaz07.pdf〉, 25.01.2018.

Chavas, J.P. \& R.G. Chambers \& R.D. Pope (2010), "Production economics and farm management: a century of contributions", American Journal of Agricultural Economics, 92(2), 356375 . 
Dudu, H. \& E. Cakmak \& Ã. Nadir (2015), "Drivers of farm efficiency in Turkey: a stochastic frontier analysis", World Journal of Applied Economics, 1(1), 45-63.

Griliches, Z. (1963), "Specification and Estimation of Agricultural Production Functions", Journal of Farm Economics, 45(2), 419-28.

Güven, A.B. (2009), "Reforming sticky institutions: Persistence and change in Turkish agriculture", Studies in Comparative International Development, 44(2), 162-187.

Huffman, W. (1976), "The Value of the Productive Time of Farm Wives: Iowa, North Carolina, and Oklahoma”, American Journal of Agricultural Economics, 58(5), 836-41.

İmrohoroğlu, A. \& S. İmrohoroğlu \& M. Üngör (2014), “Agricultural productivity and growth in Turkey”, Macroeconomic Dynamics, 18(5), 998-1017.

Keyder, Ç. \& Z. Yenal (2011), “Agrarian change under globalization: markets and insecurity in Turkish agriculture", Journal of Agrarian Change, 11(1), 60-86.

Miller, E. (2008), “An Assessment of CES and Cobb-Douglas Production Functions”, Notes on Increasing Returns, <http://homepage.newschool.edu/het//essays/product/returns.html>, 25.01.2018.

OECD, Trade and Agricultural Directorate, Monitoring Farm Support and Evaluating Policy, <http://www.oecd.org/document/59/0,3343,en_2649_33797_39551355_1_1_1_1,00.html $>$, 25.01.2018.

Olhan, E. (2006), “The impact of the reforms: impoverished Turkish agriculture”, Agricultural Journal, 1(2), 41-47.

Ozsabuncuoglu, I.H. (1998), "Production function for wheat: a case study of Southeastern Anatolian Project (SAP) region", Agricultural Economics, 18(1), 75-87.

Pamuk, S. (2008), “Agriculture and Economic Development in Turkey, 1870-2000”, in: P. Lains \& V. Pinilla (eds.), Agriculture and Economic Development in Europe since 1870, Routledge Publishers, 375-96.

Semerci, A. \& A. Mazid \& K.N. Amegbeto \& M. Keser \& A. Morgounov \& K. Peker \& S. Karabak (2012), "The production functions of wheat production in Turkey", Bulgarian Journal of Agricultural Science, 18(2), 240-253.

Sensoy, S. \& M. Demircan \& Y. Ulupinar \& I. Balta (2008), Climate of Turkey, Turkish State Meteorological Service.

Tan, S. \& N. Heerink \& F. Qu (2006), "Land Fragmentation and its driving forces in China", Land Use Policy, 23(3), 272-285.

Tintner, G. \& O.H. Brownlee (1944), "Production functions derived from farm records", Journal of Farm Economics, 26(3), 566-571.

Tintner, G. (1944), "A note on the derivation of production functions from farm records", Econometrica, Journal of the Econometric Society, (1), 26-34.

Ucak, H. (2006), "Monitoring Agriculture of Turkey before Accession Process for European Union Membership", Journal of Central European Agriculture, 7(3), 545-548.

Uysal, Y. \& Ö.K. Uysal (2006), "Price and Income Stability in Turkish Agriculture: An Evaluation of the IMF Led Agricultural Policy Changes", Politica Agricola Internazionale, 2005(12-3), 51-67. 